\title{
TUMOURS AND CANCERS IN GRAECO-ROMAN TIMES
}

\begin{abstract}
In Graeco-Roman times all tumours (Greek: onkoi, abnormal swellings) were considered to be of inflammatory origin, the result of unfavourable humoural fluxes, and caused by an extravascular outpouring of fluid into tissue spaces. The neoplastic nature of tumours is a more recent concept, barely two centuries old. In Hippocratic literature tumours were mainly classified as karkinômata, phumata and oidêmata. Phumata included a large variety of tumours, inflammatory and neoplastic in origin, and mostly benign (in modern terms), whilst oidêmata were soft, painless tumours and even included generalised oedema (dropsy). Although all categories possibly included occasional cancers, the vast majority of what appears to have been malignant tumours were called karkinoilkarkinômata (Latin: cancrum/carcinoma). There was however no recognition of benign and malignant, or primary and secondary tumours, in the modern sense.
\end{abstract}

\section{INTRODUCTION}

Herodotus tells us that at the turn of the $6^{\text {th }}$ century BC, Atossa, the wife of Darius the Great, was cured of a breast tumour (phuma) by a captive Greek physician, Democedes. ${ }^{1}$ L.J. Rather (1978:8-10) suggests that the readiness with which Democedes promised a cure and the ease with which he attained this, points at a benign breast tumour rather than a cancer. The Hippocratic writings mention a woman from Abdera who had a breast tumour and a bloody discharge from the nipple, was diagnosed as having a karkinoma, and died of the lesion. ${ }^{2}$ This was most likely a cancer as we know it today. However, the Graeco-Roman theories of tumour formation and carcinogenesis differed radically from our modern concepts which originated as late as the $19^{\text {th }}$ century. In the present study the theories of tumour formation in antiquity and the nature of tumours reported are reviewed.

1 Histories III.133-4.

2 Epidemics V.101. 


\section{THEORIES OF TUMOUR FORMATION}

In antiquity all tumours were considered to be of inflammatory origin and explained with reference to the humoural theory, in vogue since early Greek times (Rather 1978:12-13). According to Celsus's classical description, inflammation was characterised by pain (dolor), redness (rubor), heat (calor) and swelling (tumor). However, pain, redness and heat were gradually restricted to "exquisite inflammation" near a body surface, while tumor was accepted as indicative of nothing more than an abnormal swelling or mass (still caused by inflammatio). This remained dogma as late as the $18^{\text {th }}$ century (Rather 1978:26).

According to the humoural theory all matter originated from four universal elements: fire, air, water and earth. These elements were brought into relation with four basic qualities (dunameis): hot, cold, moist and dry. The Hippocratic writers associated these dunameis with their four bodily humours: phlegm, blood, black bile and yellow bile. The precise associations fluctuated with time, but were eventually finalised by Galen and then remained unchanged for 1500 years: blood was associated with hot and moist (air, spring), phlegm with cold and moist (water, winter), yellow bile with hot and dry (fire, summer), and black bile with cold and dry (earth, autumn). According to Galen, perfect health depended on the right mixture (enkrasis) of hot, moist, cold and dry, and illness was caused by an imperfect balance (duskrasis).

The humours originated from ingested food. Through a process facilitated by cooking (pepsis in Greek, concoctio in Latin), digestion and subsequent maturation in blood vessels and body tissues (under influence of predominantly innate body heat), the humours evolved. Digested food (chulê) was absorbed into the portal vein and liver where yellow bile (cholê) was formed. The earthy, cold components of nutriment were converted to black bile (melaina cholê) by the spleen to strengthen the body fibres. Blood was the most important humour and phlegm was mainly a waste product.

The circulatory system (nourishing the body parts) consisted of arteries (which carried heat and pneuma or spirit, derived from inhaled air) and veins (which conveyed blood, as well as the other three humours in varying mixtures depending on local or systemic circumstances). Between arteries and veins were specialised anastomoses which only opened 
under certain abnormal conditions, e.g. fevers or trauma, pouring blood into arteries with resultant regional congestion, and interference with peripheral delivery of pneuma. Venesection allegedly alleviated this. Galen later showed that arteries did contain blood and not air, but this did not cause him to change his views on inflammation.

Galen postulated that moist inflammation, inter alia responsible for tumour formation, arose from a "flux of humours". This entailed an abnormal congestion and mixture of these substances in response to stimuli like fever, injury, fractures and over-exertion in a localised region of the body. Depending on the humoural mixtures, the type of inflammatory response would differ, e.g. with excessive yellow bile herpes developed, erysipelas was caused by very hot bile, anthrax arose from thick hot blood, and an oidêma from excess phlegm. A flux of blood and black bile caused scirrhus, capable of converting into cancer (karkinos). Black bile unmixed with blood caused karkinoi, most often in the female breast. Galen also postulated a rare form of dry inflammation, when only heat and no humour flowed to a bodily part. Then tumour formation was impossible.

Tumours thus arose from localised inflammation when flux caused exudation of fluid from the veins into the fleshy (sarks) or parenchymal components of the body part (parenchuma). This happened because the tissues had acquired an abnormal ability to extract fluid, or because an abnormal mix of intravascular humours facilitated the extravasation of fluid. Accumulated extravascular fluid could be broken down (diaphtheretai) to form a fully concocted mixture (materia peccans) which was either gradually absorbed, discharged as septic residue (abscess), or remained indefinitely as a tumour which could have various characteristics. Soranus ${ }^{3}$ used the word onkos to cover all tumours whatever the nature.

In the Hippocratic writings there is reference to various kinds of tumours:

1. Karkinos, karkinôma (Latin: cancrum, carcinoma). Although not always indicative of cancer as we know it, many of the reported cases ${ }^{4}$ pro-

3 Gynecology III.35 and 36.

4 Epid. V.101; VII.111; Aphorisms II.15; VI.7, 38; VII.8; Ancient Medicine 22.60. 
bably do represent cancer. The name is derived from the Greek for "crab" because of a fancied resemblance of the tumour to this animal with its hard and rough exterior, and its long projections (feet and claws) into the tissues, onto which it adheres tenaciously (Rather 1978:16). The verb karkinot refers to the process of converting to cancer and was used with reference to cancerous change in certain lesions of the female genitalia (Rather 1978:9-10).

2. Phuma. ${ }^{5}$ An inclusive term which encompassed a great variety of predominantly non-malignant and inflammatory tumours.

3. Oidêma. ${ }^{6}$ A soft, usually non-tender tumour, sometimes pitting on pressure. It probably included gross oedema of the body.

Other terms for tumours, less often used in ancient literature, included scirrbus, struma, melicerides, condyloma, tuberculum, occalescit, and carcinode.

\section{TUMOURS DESCRIBED IN LITERATURE}

\subsection{Karkinos, karkinôma}

When Hippocrates ( $5^{\text {th }}$ century BC) states in the Aphorisms that it is better not to treat internal cancers as this shortens life, the term karkinos is used. ${ }^{8}$ As mentioned above, this term is also used regarding the woman from Abdera who died of a breast tumour which presented with a bloody discharge from the nipple. In the Epidemics a patient is described with a karkinoma of the pharynx which was cured by cautery. ${ }^{9}$ This is perhaps less likely to have been a true cancer in the modern sense. Retsas (1986:42-5) claims that a Hippocratic work, On carcinosis, was mentioned by Bacchius in the $2^{\text {nd }}$ century $\mathrm{BC}$, but no longer survives.

Cato the Elder (234-149 BC), the inveterate proponent of cabbage as a panacea for illnesses, claimed that a cabbage poultice will heal

5 Aph. VII.8; Glands 17; Epid. II.1.7.

6 Airs, waters and places VII.30; Prognostic VII.10; Aph. VI.7; VII.8.

7 Celsus, De Medicina II.1.19; V.18.5, 23 and 26; VII.14.1; Galen, De tumoribus praeter naturam K.VII c.9; Soranus, Gyn. IV.4.

8 Aph. VI.38.

9 Hipp. Epid. VII.111. 
all kinds of ulcers and swellings, and in particular a carcinoma of the breast. ${ }^{10}$ Celsus ( $1^{\text {st }}$ century AD) also used the term carcinoma to describe a strange ulcerating and incurable lesion of the upper part of the body, but which also involved the spleen. He mentions that the Greeks called it malignant (kakoêthes), but that it was impossible to distinguish between those lesions associated with rapid death and those with a long survival. In describing a progressive ulceration of the penis, Celsus uses the word cancrum. This might well have represented a true cancer, but he goes on to say that unless rapidly cauterised, it will develop into a phagedaena, a necrotising condition associated with blackening of the skin and total destruction of the organ. ${ }^{11}$ Elsewhere, when dealing with surgical removal of urinary stones, he uses the word cancrum or cancer to describe a very serious complication of this procedure. ${ }^{12}$ However, this almost certainly represents a rapidly spreading sepsis, even gangrene, rather than a malignant tumour. Similarly his therioma resembles necrotising ulceration rather than carcinoma.

Galen ( $2^{\text {nd }}$ century AD) recognised incipient cancers (karkinoi genomenoi) and applied deadly nightshade (solanum nigrum) in the treatment of ulcerated cancers (bêlkêkoi karkinoi). ${ }^{13}$ He recognises a variety of hard ulcerating and non-ulcerating nodular lesions (karkinoi) of the breast, uterus, male and female genitalia and elsewhere which carried a bad prognosis unless properly treated. His treatment consisted of initial "emptying of melancholic humours" (through venesection) (Fig. 30). followed by surgery (complete resection of all vestiges of tumours) and supplementary topical and systemic remedies. He echoes Hippocrates in stating that only superficial cancers should be treated this way (Retsas 1986:48-52).

Leonides, a contemporary of Galen, described total mastectomy for those cancers not attached to the thoracic wall (Retsas 1986:48-50). Retsas (1986:50-52) also lists Rufus ( $2^{\text {nd }}$ century AD), Philumenis $\left(2^{\text {nd }}\right.$ century), Oribasius ( $4^{\text {th }}$ century), Aetius $\left(6^{\text {th }}\right.$ century) and Paul of

10 On agriculture 156.1-157.4.

11 Med. VI.18; V.28.2.

12 Ibid. V.18; V.28.2.

13 Ad Glauconem de medendi methodo II.12, K.XI.143; De simplicium facultatibus VIII.19, K XII.146. 


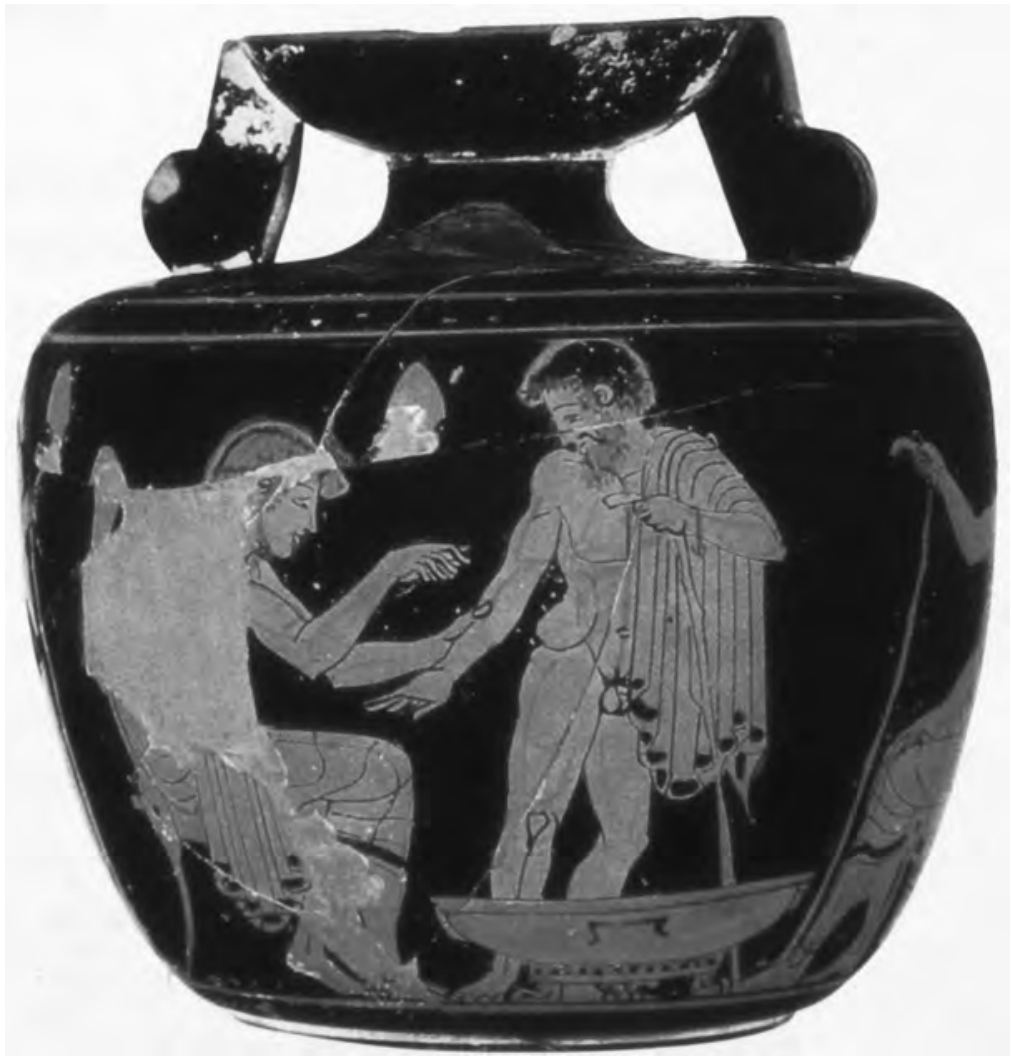

Figure 30: Doctor performing venesection. Red figure vase, $5^{\text {th }}$ century BC. Louvre Museum, Paris.

Aegina ( $7^{\text {th }}$ century) as physicians of antiquity who described lesions which could have been cancers. Dioscorides ( $1^{\text {st }}$ century AD) recommended specific ointments for a karkinos, e.g. of the nose. ${ }^{14}$ He used cantharidin against a tumour called karkinôdê, but Celsus refers to carcinode as a benign variety of phuma. ${ }^{15}$

14 Dioscorides, De Materia medica II.12.

15 Med. V.18.23. 


\subsection{PhumalPhumata}

Under this heading were included a vast array of tumours ranging from minor skin nodules to large pelvic tumours obstructing labour. In the Hippocratic writings many of these tumours were quite non-specific and ill-defined. However, the urethral phuma mentioned in Aphorisms IV.82 and internal phuma of Aphorisms VII.8 probably refer to infective tumours, even abscesses. Scrofulous tumours referred to in Glands 7 were almost certainly of infective nature, as were the para-aortic tumours (possibly renal cysts or abscesses) associated with kidney stones in Nature of Man c.14. The abscesses and tumours (phumata) mentioned in Ancient Medicine XXII.60 are of quite uncertain nature. The small mammary tumours (also called tubercles) associated with lactation, mentioned in Glands c. 17 could have been fibroadenosis or innocent retention cysts - and one might speculate that Atossa's breast tumour (phuma, mentioned above) could well have been an abscess or tumour of this nature.

In his description of penile disease, Celsus refers to excrescences (phumata) appearing on the glans before cancrum sets in. He also described a variety of small skin tumours. Many would seem to be minor infective lesions, and apparently easily cured by local applications among them meliceridis (favi) and carcinode. ${ }^{16}$ Dioscorides ${ }^{17}$ suggested colchicine applications for phumata not yet producing pus. Phumata empua were suppurating lesions (possibly even tuberculous lymph nodes). Phumata sklêra were hard tumours in the breast which did not suppurate, but became increasingly harder and could develop into karkinoi kruptoi (occult cancers) (Rather 1978:9-13).

Soranus ( $2^{\text {nd }}$ century AD) quotes Herophilus ( $3^{\text {rd }}$ century BC) when he states that abscesses and tumours in the pelvis may obstruct labour. These non-specific tumours are also referred to as phumata. ${ }^{18}$

16 Ibid.V.18.20 and 23.

17 Mat. med. IV.84

18 Gyn. iv.4-5. 


\subsection{Oidêma}

When Hippocrates writes about swelling of the hypochondrium, he refers to a lesion which is soft, painless and pits on finger pressure, as oidêma - with a better prognosis than hard swellings, but nevertheless indicative of protracted illness. ${ }^{19}$ Elsewhere, dropsy appearing in undernourished persons is referred to as oidêmata, as well as pelvic tumours causing leucorrhoea in women. And when the causes of abdominal swellings (oidêmata) are discussed in the Aphorisms (VI.7), abdominal wall swellings are said to have a better prognosis than deep swellings.

Dioscoride ${ }^{20}$ recommends cabbage, colchicine in wine, or cucumber for soft swellings (oidêmata) without defining them. Galen is also vague about the exact nature of oidêmata, and seems to accept generalised dropsy as a manifestation of it, but does include it in the same category of tumours which could well have been malignant growths. $\mathrm{He}$ prescribed three specific herbs for the treatment of oidêmata. ${ }^{21}$

\subsection{Other}

Galen defines skiros (scirrhus) as a hard and painless swelling which might arise spontaneously, develop in an area of inflammation (like erysipelas), or originate from an oidêma "when excessively cooled". It could give rise to a karkinos. ${ }^{22}$ The word struma according to Galen ${ }^{23}$ refers to a hardening of lymph nodes, while Celsus uses the same word for scrofulous tumours (Latin: swollen neck glands), which might well have represented tuberculous lymphaderopathy. ${ }^{24}$ Anal kondulômata (Greek for callous lump) were considered of infective origin although some kondulômata could well have been malignant neoplasms. ${ }^{25}$ Celsus uses the Latin word occalescit (a hardening of the skin) to refer to a callosity of the penis; nasal polyps are described as carbunculae (Latin: fleshy protuberances), and gingival gumboils as parulides, while the term

19 Airs, waters and places 7; Prognostic 7; Aph. VI.7.

20 Mat. med. IV.84 and 150; II.121.

21 Ad Glauc. de med. meth. II.12, K.XI.143; De simpl. fac. VIII.19, K XII.146.

22 De tumoribus c. 9.

23 Ibid. c. 15.

24 Med. V.28.7; V.18.13.

25 Ibid. VII.30. 
tuberculum simply signified a very small tumour. ${ }^{26}$ The word kêria occurring in the Hippocratic writings, has been translated as a malignant (Greek: deina) cyst. ${ }^{27}$ However, "malignant" does not necessarily carry the modern connotation as in malignant neoplasm. The original Greek words were deina "fearful", "terrible" in the sense of something which is to be regarded with awe because it passes human understanding) and kakoêthês ("malicious", "abominable"), and referred to both infective and neoplastic lesions (in modern jargon). The Latin word vitiosa (meaning corrupt, vicious), used by Celsus, is also translated as malignant. ${ }^{28}$ The Hippocratic Aphorism VI.4 is usually translated as stating that an ulcer with a pealing edge is malignant (Greek: kakoêthês). Therioma is often considered synonomous with malignancy but Celsus's original descrip$\operatorname{tion}^{29}$ fits in better with a very severe, spreading infection.

\section{DISCUSSION}

In Graeco-Roman times the concept tumour (onkos in Galen's terminology) embraced all abnormal swellings of the human body, and were explained on the basis of inflammation as understood within the humoural theory (Rather 1978:9-13). Abscesses and neoplasms (in the modern sense) thus simply represented different phases of the same inflammatory process. Tumours resulted from accumulation of extravascular fluid and not from overgrowth of body tissues (neoplasia, as first described in the $19^{\text {th }}$ century) - and the concept of benign or malignant tumours was thus non-existent. As blood-letting (venesection) was considered beneficial to relieve inflammatory congestion, it was considered efficacious for the treatment of all tumours. Similarly cautery, application of caustic substances and excision was random therapy for all superficial tumours, even severe ulceration. Extensive lists of local tumour applications are given by Dioscorides and others (Riddle 1985:319-330).

26 Celsus, Med. VI.18.8; VII.14.8.

27 Prorrbetic II.32.

28 Celsus, Med. VII.14.

29 Med. V.28.3. 
However, while phuma and oidêma applied to tumours which apparently were predominantly benign in the contemporary sense, it is clear that karkinos/karkinoma (fore-runner of our own word "cancer") was recognised by the ancients as having a bad prognosis, often causing death. We cited reported cases of these lesions affecting the female breast and genitalia, the pharynx, penis, nose, "chronic ulcers", "the upper part of the body”, and internal organs. Four chapters of Soranus' Gynecology (Book IV.5-8) were devoted to tumours of the uterus, but are unfortunately lost to us.

Galen warned that while it was possible to fully excise some superficial cancers (Retsas 1986:48-52), Hippocrates had said that cancers of internal organs should not be treated, as this shortened life, ${ }^{30}$ and Celsus wrote that carcinoma were incurable. ${ }^{31} \mathrm{He}$ also found it impossible to predetermine which growths would respond to therapy. ${ }^{32}$ Dioscorides's and Celsus's carcinode was probably a benign skin condition. The concept that a "benign" lesion could turn into a cancer is embodied in what Galen called "incipient cancer" (karkinos genomenos) as well as in the Hippocratic views that hard mammary growths (phumata sklêra) which did not suppurate, turned into occult cancers (karkinoi kruptoi), and that ulcers of the female genitalia, wrongly treated, became cancerised (karkinothenai ta helkea) (Rather 1978:9-13). The ancients were thus aware of pre-malignant conditions.

Celsus's description of what possibly represents a penile cancer, obviously includes severe associated septic balanitis, infectious phumata of the glans and spreading phagedaena (a "tissue eating" process)..$^{33}$ Celsus considered this part of the cancerous lesion, but it could as well have been the necrotising, gangrenous infection we today know as phagedena (usually seen in neglected or malnourished patients). His therioma could likewise have been a phagedenic ulcer.

The word "scirrhous" which today appears in the description of hard, sclerosing cancers, was also used by Galen to denote hard, painless swellings, some with malignant potential. Struma, today restricted to

30 Aph. VI.38.

31 Med. VI.18.

32 Med. V.28.

33 Med. VI.18.3-4. 


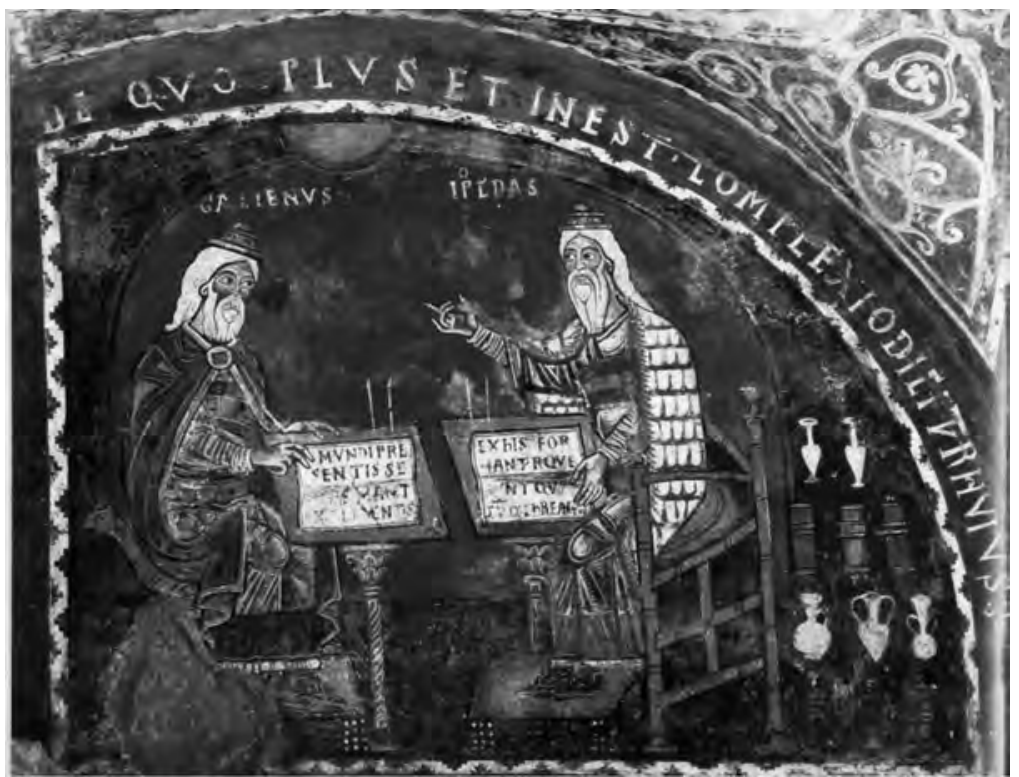

Figure 31: Galen (left) engaged in conversation with Hippocrates (right).

The fact that there were six centuries between the two giants in ancient medicine, was not taken into account in the fresco.

Cathedral in Anagni, Italy.

benign thyroid lesions, originally denoted indurated lymph nodes (possibly mainly tuberculous in origin), and condulomata were very much what they are today - benign perineal polyps usually of infective nature. Tubercle, denoting a small nodule, is today virtually restricted to lesions caused by the tubercle bacillus, and oidêma/oedema is the only major term for tumours which truly retained its original meaning an extra-vascular accumulation of fluid, either localised as in inflammatory oedema, or generalised as in dropsy or anasarca. The concept phuma has virtually disappeared except for its rare retention in words like rhynophyma for nasal enlargement in rosacea.

The ancients thus recognised that karkinômata had a much worse prognosis than phumata or oidêmata, but they did not differentiate be- 
tween malignant and benign tumours in the modern sense. They certainly had no concept of a malignant tumour metastasising to the rest of the body. When the word "malignant" appears in English translations of works of this period, it refers to Greek (e.g. deina, kakoêthês) and Latin (e.g. vitiosa) words which simply meant "terrible" or "vicious" with reference to both infective and true tumours which proved resistant to therapy. But it is likely that they were often describing tumours that we would indeed consider malignant.

\section{REFERENCES}

\section{CATO The Elder}

1934. On agriculture (transl. W.D. Hooper \& H.B. Ash). London: W. Heinemann. Loeb Classical Library.

\section{CELSUS}

1938. De Medicina (transl. W.G. Spencer). London: W. Heinemann. Loeb Classical Library. Vols. II and III.

\section{DIOSCORIDES}

2000. De materia medica. Being an herbal with many other medicinal materials. A new indexed version in modern English by T.A. Osbaldeston \& R.P.A. Wood. Johannesburg: Ibidis.

GALEN

1975. De tumoribus praeter naturam (transl. J. Reedy). Clio Medica 10(3):227-238.

\section{Herodotus}

1972. The histories (transl. A. de Selincourt). $2^{\text {nd }}$ ed. Penguin Books.

\section{HIPPOCRATES}

1923. Ancient medicine. Airs, waters and places. Epidemics 1 \& 3. The oath. Precepts. Nutriment (transl. W.H.S. Jones). London: W. Heinemann. Loeb Classical Library Vol. I. 


\section{Tumours and cancers in Graeco-Roman times}

1923. Prognostic. Regimen in acute diseases. The sacred disease. The art. Breaths. Law. Decorum. Physician. Dentition (transl. W.H.S. Jones). London: W. Heinemann. Loeb Classical Library. Vol. II.

1931. Nature of man. Regimen in health. Humours. Aphorisms. Regimen 1-3. Dreams. Heracleitus. On the Universe (transl. W.H.S. Jones). London: W. Heinemann. Loeb Classical Library Vol. IV.

1994. Epidemics (transl. W.D. Smith). London: W. Heinemann. Loeb Classical Library. Vol. I and VII.

1995. Places in man. Glands. Fleshes. Prorrhetic 1-2. Physician. Haemorrhoids and Fistulas (transl. P. Potter). London: W. Heinemann. Loeb Classical Library Vol. VIII.

RATHER L J

1978. The genesis of cancer. Baltimore \& London: John Hopkins University Press.

\section{RETSAS S}

1986. Palaeo-oncology. The antiquity of cancer. Athens: Farrand Press.

\section{RIDDLE J M}

1985. Ancient and medieval chemotherapy for cancer. Isis 76:319-330.

\section{SORANUS}

1956. Soranus' Gynecology (transl. O. Temkin). Baltimore \& London: The John Hopkins University Press. 